Meta

Journal des traducteurs

Translators' Journal

\title{
La fonction heuristique de la traduction
}

\section{Barbara Folkart}

Volume 35, numéro 1, mars 1990

Actes du colloque international « La traduction proligère "

URI : https://id.erudit.org/iderudit/002754ar

DOI : https://doi.org/10.7202/002754ar

Aller au sommaire du numéro

\section{Éditeur(s)}

Les Presses de l'Université de Montréal

\section{ISSN}

0026-0452 (imprimé)

1492-1421 (numérique)

Découvrir la revue

\section{Citer cet article}

Folkart, B. (1990). La fonction heuristique de la traduction. Meta, 35(1), 37-44. https://doi.org/10.7202/002754ar

\section{Résumé de l'article}

Translation is usually viewed as a process designed to overcome a deficiency: $\mathrm{X}$ translates the words of A for C, because $\mathrm{C}$ doesn't have an adequate command of the language in which A expressed himself. Translation so practised is usually, if not always, an entropie process. As I think I have shown in a recent article, there is a strong tendency of the text to run downhill in translation, with a demonstrable loss of ordering and coherency, an inexorable regression of form to formants, of the marked to unmarked1.

There exist, however, cases where translation ceases to be a mere expedient and, far from being entropie, conserves or even enhances the ordering of the texts it brings into play. It is in such cases that translation may be said to function heuristically, by foregrounding structures taken for granted in the source text, by making the information encoded in the text more readily accessible to the target-language group than it was to the source-language group, by enhancing the repertory of esthetic forms available to the target-language group, or by stimulating the creation of new forms.

A number of more or less canonical examples come to mind immediately. Ethno-linguistic translation zeroes in on what I have referred to elsewhere as the grain of the text (i.e. the micro-structures that derive from the linguistic substratum2), in order to provide insights into the functioning of languages very different from that of the target group. In hermeneutic translation, the usually subterranean work of interpretation surfaces quite explicitly in the target text, which thus functions as a gloss, making the message more readily available to the target-language reader than it was to start with in the source text3.

But the heuristics of translation can go far beyond the narrow scope of such undertakings.
Ce document est protégé par la loi sur le droit d'auteur. L'utilisation des services d'Érudit (y compris la reproduction) est assujettie à sa politique d'utilisation que vous pouvez consulter en ligne.

https://apropos.erudit.org/fr/usagers/politique-dutilisation/ 


\section{LA FONCTION HEURISTIQUE DE LA TRADUCTION}

BARBARA FOLKART

University of Ottawa, Ottawa, Canado

Translation is usually viewed as a process designed to overcome a deficiency: $\mathrm{X}$ translates the words of $\mathrm{A}$ for $\mathrm{C}$, because $\mathrm{C}$ doesn't have an adequate command of the language in which A expressed himself. Translation so practised is usually, if not always, an entropic process. As I think I have shown in a recent article, there is a strong tendency of the text to run downhill in translation, with a demonstrable loss of ordering and coherency, an inexorable regression of form to formants, of the marked to unmarked ${ }^{1}$.

There exist, however, cases where translation ceases to be a mere expedient and, far from being entropic, conserves or even enhances the ordering of the texts it brings into play. It is in such cases that translation may be said to function heuristically, by foregrounding structures taken for granted in the source text, by making the information encoded in the text more readily accessible to the target-language group than it was to the source-language group, by enhancing the repertory of esthetic forms available to the targetlanguage group, or by stimulating the creation of new forms.

A number of more or less canonical examples come to mind immediately. Ethnolinguistic translation zeroes in on what I have referred to elsewhere as the grain of the text (i.e. the micro-structures that derive from the linguistic substratum ${ }^{2}$ ), in order to provide insights into the functioning of languages very different from that of the target group. In hermeneutic translation, the usually subterranean work of interpretation surfaces quite explicitly in the target text, which thus functions as a gloss, making the message more readily available to the target-language reader than it was to start with in the source text ${ }^{3}$. takings.

But the heuristics of translation can go far beyond the narrow scope of such under-

\section{LA TRADUCTION À LA DÉCOUVERTE DE L'AUTRE}

André Lefevere avait déjà signalé la valeur heuristique que la traduction pouvait revêtir pour la littérature comparée ${ }^{4}$. Il avait raison en principe. Mais seulement à condition que le traducteur fasse sienne cette visée éthique qui consiste à amener sur les rives de la langue traduisante l' cuvre étrangère dans sa pure étrangetés.

Or cette entreprise de découverte peut être compromise d'avance par des facteurs intervenant à deux niveaux distincts. Il y a d'abord ce refoulement qu'Antoine Berman a dénoncé dans une série d'écrits magistraux que Ghyslain Charron a extrapolé du domaine de la psychanalyse à celui de la recherche en faisant remarquer que «si le refoulement n'est pas un vain mot, nous cherchons autant à ne pas savoir qu'à savoir ${ }^{6}$ ». Et, même une fois vaincu le refoulement, des limitations plus insidieuses encore peuvent empêcher d'accueillir l'œuvre étrangère dans sa pure étrangeté. Intervient, en effet, à ce deuxième stade, le plus souvent à l'insu du traducteur, un phénomène de filtrage: lorsque le texte de départ relève d'une matrice culturelle très éloignée dans le temps ou dans l'espace, le traducteur aura tendance à plaquer sur lui la grille fournie au préalable par le polysystème d'arrivée. 
Maria Tymozcko ${ }^{7}$ a étudié en diachronie cette emprise du polysystème, en mettant en évidence les pressions assimilatrices exercées par un polysystème récepteur, celui de l'anglais, sur les traductions d'une ancienne épopée irlandaise, genre dont le contenu archaïque et la complexité formelle le situaient à une distance maximale du canon de formes reçues.

L'intégration de l'épopée au système récepteur s'est faite par approches successives du texte, approches rendues possibles, tant au niveau de la saisie qu'au niveau de la reproduction, par l'évolution du polysystème d'arrivée. Ces saisies de plus en plus affinées vont de l'étape du texte d'arrivée monolithe, toute prose ou tout vers, à l'étape du prosimetrum, différenciation binaire qui oppose une prose indifférenciée à une prosodie indifférenciée, pour aboutir, avec la traduction du poète Thomas Kinsella en 1969, à l'étape de la stratification à cinq niveaux, différenciation qui rend finalement justice à la complexité formelle de l'ancienne épopée et qui a été rendue possible par l'existence dans le polysystème anglais, depuis Joyce, de proses polylangagières.

Ainsi s'est opérée une sorte de réfraction de l'épopée à travers le polysystème récepteur, filtrage analogue à celui qui se produit lorsque tel bruit naturel - le chant du coq, pour prendre l'exemple canonique - est passé au crible du système phonologique pour en sortir sous forme d'onomatopée - cock-a-doodle-doo ou cocorico, selon qu'il a été passé par le filtre phonologique de l'anglais ou du français. C'est l'évolution du polysystème-crible qui explique qu'il soit possible de nos jours non seulement de reproduire mais même de percevoir la stratification à cinq termes, car l'on ne re-connaît que ce que l'on a déjà appris à connaître.

Si la dernière en date des traductions rend mieux compte que ses prédécesseurs de la textualité de l'ancienne épopée, c'est moins de par sa volonté d'amener le lecteur au texte que parce que l'évolution du polysystème récepteur, qui s'était enrichi entretemps de la polylogie d'un James Joyce, le permettait ${ }^{8}$.

Ainsi, paradoxalement, la puissance de la traduction comme instrument de découverte peut-elle être limitée par le fait que le traducteur le mieux intentionné risque fort de ne trouver à l'étranger que ce qui existe déjà chez lui. Se soustraire à la pesanteur de son propre polysystème pour appréhender, dans sa pure étrangeté, un texte très éloigné dans le temps ou dans l'espace exige une véritable ascèse, un effort sans relâche pour se dépouiller de ses habitudes culturelles. Le rendement heuristique de ce type de traduction est donc proportionnel au degré de rigueur intellectuelle, opératoire et éthique dont aura su faire preuve le traducteur.

\section{TRANSLATION AS AN INSTRUMENT OF SELF-DISCOVERY}

Ultimately, perhaps, the whole purpose of learning about other literatures and about others is to learn more about one's own literature, and about one's self, surely a heuristic undertaking of the first magnitude. As Jacques Brault put it, «le rapport vital de soi à soi passe par la médiation d'autrui ${ }^{9} \gg$. Consider for example what would happen if, as a purely conceptual experiment, one were to translate into English, specifically for an American readership, a book like Michel Butor's Mobile. Mobile, as Butor himself put it, was conceived as a patchwork of quotes taken from the social text of everyday American culture in the late fifties, together with its historical and ideological underlay, and pieced together to give a highly impressionistic description of that culture. What the book really describes, of course, is a perception that is to a very considerable extent pre-conditioned by the topoï concerning the United States that were so prevalent in France at the time it was written (comme à la proverbiale auberge espagnole, Butor n'a mangé que ce qu'il avait apporté). In other words, this book reveals at least as much about the observer as about the observed. 
Translating such a book for an American reader would at first sight seem to be one of those ludicrously self-referential operations which ricochet back and forth inside a sealed literary space, never escaping the pull of the text and never impinging on outside reality. After all, from a strictly cognitive standpoint, the American reader has no need to be told that:

Le poison ivy est une liane à feuilles pointues groupées par trois, rougeâtres à l'extrémité quand elles sont jeunes. Leur contact produit des boutons, démangeaisons, qui peuvent être accompagnés de fortes fièvres, durer des semaines et revenir périodiquement. Cette infection est contagieuse ; même les cendres la provoquent [Butor (1962) : 37].

From a pragmatic and ethical standpoint, however, it might have been very interesting for an American of the early sixties to realize how his culture was perceived by this latter-day Huron returned a couple of centuries later to scrutinize the United States with the same uncompromisingly critical outsider's stare that his Voltairian prototype had turned on 18 th century France.

I would argue that the values generated by translation performed under such conditions - assuming, of course, that the very real literary qualities of the original could be preserved - would transcend those produced by the text $a b$ quo. Whereas the source text merely confirmed the French reader's pre-established view of the United States, the target text would impell the American reader outside himself; the moral superiority and smugness generated by the original would give way, in the context of an American reading, to a sense of moral discomfort; the self-indulgence of the myth that racism only exists elsewhere would be replaced by a long, cold hard look at one's world as it is perceived by a disapproving other, and, to some extent, as it really is. The skewing or decentering thus produced would constitute a value added by the translation process: instead of merely filling in for the source text, the target text would perform a radically different function.

\section{TRADUCTION ET SURCOMPÉTENCE}

Dans les cas envisagés jusqu'ici, le texte d'arrivée, traversé par la visée heuristique, avait une valeur purement instrumentale. Il existe par contre des cas où le texte d'arrivée (ou plutôt la configuration texte de départ + texte d'arrivée), au lieu d'être transcendée par la découverte qu'elle rend possible, engendre, en et par elle-même, des valeurs qui lui sont immanentes. Nous aborderons ainsi des cas où la traduction, proligère au plus haut degré, crée des valeurs qui ne sauraient sans elle exister. On peut parler alors d'un véritable surcroît traductionnel: texte de départ et texte d'arrivée jettent l'un sur l'autre un éclairage herméneutique, esthétique ou autre de nature à les fusionner en ce type de constellation sui generis auquel Nicholas Rand a donné le nom de «symbole» ${ }^{10}$. Le texte de départ se lit en filigrane à travers le texte d'arrivée (ce qui, bien entendu, présuppose chez le récepteur une compétence bilingue et biculturelle très poussée), le texte d'arrivée ajoutant désormais ses propres résonances au texte de départ, l'un et l'autre se complétant comme les deux moitiés du symbolon.

Ainsi, pratiquée, la traduction est caractérisée par une sorte de rétroaction herméneutique analogue à celle qui existe en psychanalyse, où «la causalité psychique va autant dans le sens présent-passé que dans le sens passé-présent ${ }^{11}{ }^{1}$. D'unidirectionnel ${ }^{12}$, le parcours entre le texte $a b$ quo et le texte ad quem devient bidirectionnel.

Appartient à ce plus privilégié des cas, sans doute, le texte anglais écrit par $\mathrm{G}$. $\mathrm{R}$. Nicholson à partir d'un rondeau de Charles d'Orléans : 


\section{Charles d'Orléans \\ (cité par Holmes dans Meta 17-2)}

\author{
Jeunes amoureux \\ nouveaulx, \\ En la nouvelle saison, \\ Par les rues, sans \\ raison, \\ Chevauchent faisans les \\ saulx.
}

Et font saillir des

carreaulx

Le feu, comme de

charbon:

Jeunes amoureux

nouveaulx

en la nouvelle saison.

Je ne sçay si leurs
travaulx
Ilz employent bien ou
non;
Mais piqués de l'esperon
Sont autant que leurs
chevaulx,
Jeunes amoureux
nouveaulx.

\author{
G. R. Nicholson \\ (cité par Holmes dans \\ Meta 17-2) \\ Young rockers with a bird in \\ tow, \\ Now the long evenings are \\ here, \\ Revving their engines, \\ changing gear, \\ Up and down the streets they \\ go. \\ They do a ton-up, just for \\ show, \\ Along a stretch not far from \\ here: \\ Young rockers with a bird in \\ tow \\ Now the long evenings are \\ here. \\ Whether they're having it or \\ no \\ I'm left to wonder, but it's \\ clear \\ The engine's music in their \\ ear \\ Speaks for the urge that \\ works them so, \\ Young rockers with a bird in \\ tow.
}

On constate, dans la ré-écriture de Nicholson ${ }^{13}$, un certain nombre de déplacements. Ce qui frappe d'abord, c'est le recentrement de la thématique, qui a maintenant pour origine des coordonnées le système du ré-énonciateur, l'Angleterre des années soixante (noter que ce recentrement même a pour effet d'affirmer la pérennité de la thématique, cette affirmation constituant à son tour une des valeurs ajoutées par la traduction). Plus remarquable encore est la tension entre une prosodie encore courtoise et une thématique réactualisée dans un registre résolument prolétaire, entre connotés sociolittéraires et connotés pragmatiques, donc. En ce qui est de l'insertion polysystémique, finalement, on note un certain déplacement du texte, qui, avec sa versification désormais inusitée et son registre quelque peu trivialisé, passe du centre à une position plus périphérique. (Et c'est dans ces «déplacements» que réside bien entendu la valeur ajoutée par la traduction: si le texte d'arrivée n'était que la simple réplique du texte de départ, il ne pourrait pas former, avec celui-ci, un symbole.)

Ces tensions n'existaient bien entendu pas dans l'original. Mais elles n'existent pas non plus comme pure immanence en dehors de toute référence au protopoème qui forme l'autre moitié du symbole, dans le texte de Nicholson pris isolément. Certes, on pourrait imaginer, dans un poème écrit directement, une tension comparable entre prosodie et thématique - rien n'empêche en effet un poète du $\mathrm{XX}^{\mathrm{e}}$ siècle de s'exprimer à travers la prosodie du $\mathrm{XV}^{\mathrm{e}}$ siècle - mais on voit difficilement ce qui, en dehors d'un parti pris d'intertextualité ponctuelle ou générique, pourrait motiver un pareil porte-à-faux, et faute de motivation le poème manquerait d'organicité. Le lieu de toutes ces tensions est donc le 
symbole, cette constellation formée par les deux textes lus l'un à travers l'autre. Comme le jeu intertextuel, le symbole n'atteint son plein rendement que par la superposition stéréoscopique du texte de départ et du texte d'arrivée. Le whether they' re having it or no du métapoème paraîtrait tout simplement un peu trivial, n'était-ce la valeur subversive qu'il crée en outrant le vers de Charles d'Orléans. Même les faiblesses du texte d'arrivée se résorbent dans le texte de départ: la dernière strophe subit une légère perte de motivation avec la transposition de la métaphore, mais retrouve dans le protopoème la plénitude de sa motivation. Bref, la valeur de ré-écriture n'existe que dans le symbole formé par les deux textes, l'un ne revêtant désormais sa pleine valeur que comparé à l'autre. C'est donc que la ré-écriture traductionnelle a créé une valeur sui generis.

Nous touchons ici à un cas qui est privilégié non seulement par la qualité de la traduction mais aussi par la qualité de la compétence biculturelle et bilingue que le symbole présuppose chez un ré-énonciataire capable de fonctionner en même temps comme énonciataire. Les propos de Vilas Sarang sur l'auto-traduction valent, mutatis mutandis, pour le symbole:

Not only may translation claim status as independent text, but may in its turn influence the original text...

[The case of authorial involvment] should make us see the writer's relationship to his audience in a new light. One conclusion would be that only a reader equally at home in English and French, or in English and Marathi, could hope to grasp fully the work of Beckett, or of Kolatkar. The bilingualism of the writer demands a corresponding bilingualism on the reader's part ${ }^{14}$. (C'est nous qui soulignons.)

La traduction cesse alors d'être l'auxiliaire du lecteur handicapé par son ignorance de la langue de départ, pour devenir un mode d'écriture raffiné à l'intention de récepteurs privilégiés par leur familiarité avec deux systèmes culturels. Au lieu de pallier une déficience, la traduction fait désormais appel à une sur-compétence.

\section{TRANSLATION AS A PRELUDE TO CREATION}

The cases we have envisaged so far illustrate the heuristic function of translation considered as a product. The translational process can also have a definite heuristic value.

Ezra Pound's translations of Chinese poetry, once considered recreations or free imitations, have been shown to be remarkably congruent with the poetics of the originals. Pound displayed an uncanny insight into what Wai-lim Yip has termed the «inner thought forms» of these texts he was unable to read. His translations often reflect the original far more meaningfully than did the podestrian rendreings of the Sinologists on whom he relied.

Yet, one has the sense that what faithfulness one finds here is less the residue of a mimetic intention than the result of a remarkable convergence between Pound's poetics, or rather the poetics Pound was constructing for himself and that of the ancient Chinese poets, between what Pound was trying to introduce into English poetry and what had already been done in Chinese, centuries earlier.

In Pound's Cathay, one sees translation moving beyond the mimetic. Indeed, translation was, for Pound, an aesthetically interested activity that served above all, as Ronnie Apter has pointed out, as a preparation for writing. Wai-lim Yip has noted how Pound's practice of translating poetry was informed and contamined by the way he wrote poetry: "All the poems in Cathay are to some extent Poundian," he remarks. "Pound's translations were first land-marks of his poetry and only secondarily representations of alien cultures ${ }^{15}$," 
Whereas translation mimetically practised "always proceeds from the limits of conscious understanding ${ }^{16}$," Pound seems to have been moving even in his translations into the sphere where the unconscious comes into play, beyond recreation into creation. So obsessive is the creative impulse that the act of translating a poem becomes, inevitably, an act of poetry, the writing of "un nouveau poème relatif à une expérience de lecture poétique ${ }^{17}$."

\section{CONCLUSION}

On a tendance à enfermer la traduction dans une visée téléologique, en l'envisageant comme une pratique contrainte par le texte de départ, une activité ayant pour origine et aboutissement l'Original, un faire profondément mimétique, donc, et voué à cette clôture rigoureuse qu'est l'interdiction formelle de dépasser la texture de l'original ${ }^{18}$.

Mais on aurait tort, à mon avis, de condamner la traduction à n'être que cela, de vouloir l'enfermer dans cette éthique du mimétisme. On aura remarqué que dans tous mes exemples le texte d'arrivée manifestait une certaine altérité par rapport au texte de départ. Dans le symbole, par exemple, le métatexte, loin d'être une réplique pure et simple du prototexte, n'éclaire et ne complète celui-ci que grâce à un certain bougé. Même la traduction faite dans une visée strictement mimétique ne manquera pas d'être autre que l'original. Le mimétisme est grevé par la loi de l'entropie croissante: lorsqu'une traductrice moderne de la Chanson de Roland écrit Jamais il n'aurait sonné s'il n'était en train de combattre à la place de Unc nel sonast si ne fust combattant, la perte, rien qu'au niveau de la métrique, est irrémédiable. Dans le domaine littéraire, à tout le moins, jamais un texte repensé, ré-écrit, refait, ré-énoncé n'aura l'organicité d'un texte écrit. Même lorsque la traduction porte sur le texte le plus banal, le mimétisme est un leurre, car tout comme l'énonciation s'inscrit dans l'énoncé qu'elle produit, de même la ré-énonciation s'inscrit, à un niveau ou à un autre, dans le ré-énoncé. Même la traduction la plus probe constitue, comme toute autre ré-énonciation, une réapprobation qui fait passer le dit d'autrui par le dit du traducteur, en imposant toute une série de filtrages, tant au niveau de la réception qu'à celui de la remédiation. Bref, la traduction entreprise dans une visée de mimétisme est condamnée à être moins que mimétique.

C'est dire qu'il existe une altérité du texte traduit, une altérité inéluctable et qu'il serait malhonnête de vouloir escamoter. Cette altérité peut se manifester tout simplement comme le bougé purement mécanique imposé par la remédiation à travers un autre matériau prédiscursif et un autre univers de référence. Elle peut témoigner, par contre, d'une véritable créativité traductionnelle, la création étant, en traduction comme partout ailleurs, un processus caractérisé par des sauts quantiques et des mutations brusques, une démarche qui refuse de procéder par extrapolation à partir du déjà écrit.

Il faudrait faire une place sur les marches de la traduction à la création traductionnelle: imitations, appropriations, écritures tangentielles qui s'arrachent à la pesanteur du déjà-écrit. Écrire, dans la langue d'arrivée, un poème relatif à une expérience de lecture poétique, c'est transcender l'Original pour créer des valeurs qui ne sauraient exister en dehors de la traduction. Conçue comme une activité novatrice qui invente sa propre finalité au fur et à mesure qu'elle se déploie, la traduction cesse d'être un pis-aller destiné à combler tant bien que mal une déficience. Elle s'arrache à la clôture de l'Original, échappe à la loi de l'entropie croissante qui régit le re-dire, devient une activité pleinement heuristique.

Ce n'est qu'en assumant son altérité, voire en revendiquant le droit de se vouloir autre, lorsqu'il le faut, que la traduction peut se faire pleinement proligère. 


\section{NOTES}

1. See my «Translation and the Arrow of Time», forthcoming in TTR.

2. «La matérialité du texte : la traduction comme récupération de l'infra-discursif», META, 34:2, pp. 143-156.

3. Hence, for example, the Boutades about Hegel's being easier to read in French than in German:

Un ami allemand, philosophe de surcrôt, à qui je faisais part de mon dèsir d'êtudier la langue allemande afin de pouvoir lire et comprendre Hegel, Marx, Goethe, Novalis, Hölderlin, etc., me répondit avec un sourire narquois: "Ne vous donnez pas cette peine, du moins pour Hegel; quand je veux vraiment le comprendre, je le lis en français.» (Brault, J. (1977) : «Remarques sur la traduction de la poésie», Ellipse, 21, p. 12.)

4. «Refractions [including translations] introduce new poetological devices into a literary system. They are responsible for the migration of genres [...] styles, symbols, characters from one system to another. As such they play a double part: on the one hand, the new devices they make available may be taken up by writers producing inside the system that receives them. On the other hand they have enormous heuristic value for scholars studying literature, since they offer insight into different systems, with different poetics, and as such deepen one's knowledge of litterature in general.» (Lefevere, A. (1985): «Literary Theory and Translated Literature», Dispositio, VII: 19-20, p. 19.)

5. Berman (1985: 58).

6. «Observer, interpréter et théoriser en psychanalyse», La Revue de l'Université d" Ottawa, vol. $55, \mathrm{n}^{\circ} 4$

7. «Strategies for Integrating Irish Epics in European Literature», Dispositio, VII:19-20, (1982): 123-140)

8. Comme l'écrit Tymozcko:

«The easiest way to describe Kinsella's translation strategy would be to say that he attempted to take the audience to the text, while other translators were content to take the text to the audience. This is to some extent true. What is perhaps more accurate, however, is to note that Kinsella's translation strategy also depends on codes of the target tradition, but that the elements of the literary canon molding his translation are different from those of his predecessors. That is, in Kinsella's translation twentiethcentury literature provides the reference points for his formal codes while previous translations depend on older and more established works in the literary canon-classical literature, medieval literature, and folktale. To a large extent it is the formal changes in European literature during the sixtyyear gap between Kinsella and the previous popular translation [...] that are operative in determining Kinsella's translation strategy.» [Op. cit., p. 137]

9. Brault (1977:26).

10. «"Vous joyeuse mélodie - nourrie de crasse". Traductions: Beaudelaire, George», Poétique, 52 (1982), pp. $471-485$.

11. Charron $(1984: 81)$

12. C'est la perspective la plus courante, selon laquelle le TA n'a d'existence et d'intérêt que pour la culture réceptrice (cf. Toury, par exemple).

13. On pourrait très bien considérer que la ré-écriture de Nicholson, dans la mesure où elle recentre la thématique du poème par rapport au ré-énonciataire, constitue une adaptation plutôt qu'une traduction. Mais ce qui nous intéresse ici, c'est bien moins le statut précis de cette ré-écriture que les valeurs qu'elle crée, ainsi que le rapport dynamique qu'elle instaure entre prototexte et métatexte.

14. «Self-Translators», Journal of South-Asian Literature, 16:2 (1981), pp. 33-39.

15. Yip, Wai-lim (1969) : Ezra Pound's Cathay, Princeton, New Jersey, Princeton University Press, pp. 148 et 158.

Bien sûr, la pratique de Pound contrevient à ce que Berman a appelé «la visée éthique de la traduction»: "Amener sur les rives de la langue traduisante l' euvre étrangère dans sa pure étrangeté, en sacrifiant sa 'poétique' propre.» (Berman (1985): 58. C'est nous qui soulignons).

16. Yip (1969: 102-103).

17. Brault $(1977: 26)$.

18. Ainsi Berman (1985: 58): «[...] le contrat fondamental qui lie une traduction à son original [...] interdit tout dépassement de la texture de l'original.»

\section{BIBLIOGRAPHIE}

BERMAN, A. (1985): «La traduction et la lettre, ou l'auberge du lointain», Les Tours de Babel, Mauvezin, Trans-Europ-Repress, pp. 31-150.

BRAULT, J. (1977) : «Remarques sur la traduction de la poésie», Ellipse, 21, pp. 10-35.

BUTOR, M. (1962) : Mobile. Études pour une représentation des États-Unis, Paris, Gallimard.

CHARRON, G. (1984): «Observer, interpréter et théoriser en psychanalyse», La Revue de l'Université d'Ottawa, 55:4.

FOLKART, B. (sous presse) : «Translation and the Arrow of Time».

LEFEVERE, A. (1982) : «Literary Theory and Translated Literature», Dispositio, VII:19-20, pp. 141-162. 
RAND, N. (1982): «"Vous joyeuse mélodie - nourrie de crasse". Traductions: Beaudelaire, George», Poétique, 52, pp. 471-485.

SARANG, V. (1981) : «Self-Translators», Journal of South-Asian Literature, 16:2, pp. 33-39.

TYMOZCKO, M. (1982) : «Strategies for Integrating Irish Epics into European Literature», Dispositio, VII: 19-

20, pp. 123-140.

YIP, W. (1969) : Ezra Pound's Cathay, Princeton, New Jersey, Princeton University Press. 